Man and Nature

MAN AND NATURE

L'homme et la nature

\title{
J.M.R. Lenz as Theologian
}

\section{Timothy Pope}

Volume 2, 1984

URI : https://id.erudit.org/iderudit/1011813ar

DOI : https://doi.org/10.7202/1011813ar

Aller au sommaire du numéro

\section{Éditeur(s)}

Canadian Society for Eighteenth-Century Studies / Société canadienne d'étude du dix-huitième siècle

\section{ISSN}

0824-3298 (imprimé)

1927-8810 (numérique)

Découvrir la revue

Citer cet article

Pope, T. (1984). J.M.R. Lenz as Theologian. Man and Nature / L'homme et la nature, 2, 75-82. https://doi.org/10.7202/1011813ar
Résumé de l'article

Les premiers écrits théologiques de Lenz montrent une plus grande originalité et sont d'une plus grande importance pour le développement de l'auteur qu'on ne l'a admis. Il reconnaît dans la perte de l'Eden le premier pas de l'humanité vers sa maturité éthique et maintient que l'évolution humaine se réalise à travers l'action. Plutôt que de devenir l'objet d'un sentiment de remords, les mauvaises actions peuvent être rachetées plus tard par de bonnes actions. Lenz donne l'expression la plus élaborée à ces idées dans le drame Der Hofmeister.
Copyright (C Canadian Society for Eighteenth-Century Studies / Sociéte canadienne d'étude du dix-huitième siècle, 1984
Ce document est protégé par la loi sur le droit d'auteur. L'utilisation des services d'Érudit (y compris la reproduction) est assujettie à sa politique d'utilisation que vous pouvez consulter en ligne.

https://apropos.erudit.org/fr/usagers/politique-dutilisation/ 


\title{
J.M.R. LENZ AS THEOLOGIAN
}

\author{
Timothy Pope
}

"Ich bin also jetzt ein guter evangelischer Christ, obgleich ich kein orthodoxer bin. Kann ich in meiner Uberzeugung weiter kommen, so will ich dem Gott dafür danken, der es weiss, dass dieses das Lieblingsstudium meiner Seele ist und ewig bleiben wird."l So writes Jakob Michael Reinhold Lenz in 1772 to his friend and mentor Johann Daniel Salzmann. Theological study, which had been so much a part of Lenz's upbringing in Livonia, and then the major focus of his university years in Königsberg, and finally in Strasbourg an expression of personal conviction, had become "mein zur andern Natur gewordenes Lieblingsstudium" and was indeed to preoccupy him for many years. The discussion of theological issues with Salzmann, besides the philosophical ones usually considered as more vital to Lenz's development, led to the presentation of many papers on theology to the Société de littérature et de belles lettres (too many, said his hearers, who had begun to find Lenz's preoccupation tedious). It led also to the compilation of a private document, something like a personal notebook, commonly known as the "Lebensregeln" and usually mistakenly identified on account of its similarity of content with the missing paper, "Vom Baum des Erkenntnisses Gutes and Bösen." Out of Lenz's presentations to the Société came the two published works of a moral-philosophical and theological nature, Meynungen eines Layen of 1775 and Philosophische Vorlesungen für empfindsame Seelen of $1780 .^{2}$ Throughout the Strasbourg years theology as well as literature was a point of contact with Goethe, whose Brief des Pastors $\mathrm{zu}^{* * *}$ is referred to in the "Lebensregeln, "3 with Herder, whose Alteste Urkunde des Menschengeschlechts is invoked at the beginning of the Meynungen and which in turn makes mention of Lenz's own drama Der Neue 
Menoza, ${ }^{4}$ and with Johann Caspar Lavater, whose friendship with Lenz displayed religious fervour far beyond the usual intensity of Sturm und Drang friendships. Besides all these tokens of Lenz's overriding interest in theology is the claim Lenz himself makes for his theological magnum opus: "Die Meynungen sind der Grundstein meiner ganzen Poesie, aller meiner Wahrheit, all meines Gefühls." Clearly such an important claim needs to be examined carefully.

In general, however, scholars of Lenz who have treated of his theological writings have contented themselves with identifying influences on him, whether Spalding, Jerusalem, Mosheim, Michaelis, Salzmann (and through him Leibniz), Goethe, Herder or Lavater, 5 or they have merely traced Lenz's religious ideas back to his pietist upbringing and dismissed them as "irrational"6 or "abnormal-subjektivistisch."7 It was fashionable in the 1930s to dispose of Lenz's religious preoccupations in this way. Werner Wien, for example, sees Lenz's optimistic activism, as expressed in the theological essays, as a short-lived struggle against a fundamental overriding irrationalism, produced in him by his pietistic upbringing and fuelled by his extreme sensibility, ending, we may hardly need add, in the outbreak of insanity after Lenz's expulsion from Weimar. Since Wien, however, there has been no attempt to correct the picture. The most important book in French on Lenz, that by René Girard, published in 1968,8 consciously follows Wien's treatment of Lenzian religion, as does the survey of Lenz's life and work found in most university libraries: Ottomar Rudolf's study of Lenz as Aufklärer and moral philosopher. Other recent books in English and German have all preferred to ignore the relationship between Lenz's consciously formulated religious views and his literary work. It is my contention that neither Lenz's literary work nor his personal influence on the main Strasbourg representatives of the movement known as the Sturm und Drang can properly be appreciated without reference to Lenz's theological infrastructure.

Here also we must question a common assumption of Lenz scholarship that any originality in theological thinking will all be on the side of other thinkers than Lenz whom Lenz is supposed to have imitated. The fact that Lenz made no secret of the intended link between his work and that of other leading writers of the day does not prove his dependence on them, however suspect we may find his claims to independence, originality, and, in some cases, priority. One such case of a claim to priority is found at the beginning of Meynungen eines Layen. Lenz's fictitious clergyman, the counterpart to Goethe's Pastor $\mathrm{zu}^{* * *}$, writes: "Ich danke Innen für die zugesandte älteste Urkunde des Menschengeschlechts. Sey auch der edle Verfasser wer Er sey, Er ist ein Mann von Gott kommen! Ich möchte Ihnen eine Gegenfreude machen, nehmen Sie dies Manuscript, lesen Sie's. Ueber sechs Monate schon lag's unter meinen Papieren."9 We are to understand that the Meynungen, being mentioned in the same breath as Herder's Alteste Urkunde, are of parallel importance but that having been in existence "über sechs Monate schon," they enjoy priority over the Urkunde which is depicted as having just been published. We are inevitably reminded of an earlier claim by Lenz to priority, strongly contested later by Goethe in Dichtung und Wahrheit, 10 that his Anmerkungen über das Theater were first delivered as a paper to a "Gesellschaft guter Freunde" two years prior to the appearance of Goethe's and Herder's own manifesto, Von 
deutscher Art und Kunst. Lest it be assumed, however, that the second case is as questionable as the first, differences must be noted between the two claims to priority. The second, with its urbane approval of Herder's work, is a conventional fiction, unlike the pointed and provocative claim that had annoyed Goethe. It is also far from being misleading. Lenz's Meynungen had indeed been in existence for a good while already, since the work is a composite of several papers delivered to the Société, as the frequent appeals to an audience attest. There are comments in it that indicate a desire on Lenz's part to out-Herder Herder, but, because these comments are limited to the preface, it cannot be said that the work arose out of a reading of Herder. They were written therefore at the time of compilation, not at the time of composition. Titel and Haug have suggested that an earlier work of Herder's, his Fragmente uber di neuere deutsche Literatur of 1767 might lie behind Lenz's pose as a layman. 11 what is more certain, however, is that as early as 1772 Lenz had consciously embraced a layman's role, not as a pose but as a vocation that was more suited to him, he felt, than that to which his father had destined him. It is as a lay theologian, as well as a literary writer, that Lenz entered the Société. The frequency with which he delivered theological papers and contributed paragraphs to his notebook, "Lebensregeln," attests to the fact that from his earliest days in Strasbourg he too had worked on an Älteste Urkunde independent of Herder's, or more correctly an Erziehung des Menschengeschlechts several years before Lessing's: an interpretation, that is, of old Testament history that could be made to express and support not just Lenz's personal ethic but also the aspirations of his generation towards intensity and spontaneity of living. The salvation history traced, albeit in far less polished form than Lessing's, by the Meynungen together with "Versuch uiber das erste Principium der Moral," the two "Supplemente zur Abhandlung vom Baum des Erkenntnisses Gutes und Bösen" and the "Lebensregeln," aims to supply a rationale to the ideals of the day.

In common with Enlightenment ideas Lenz's Heilsgeschichte proceeds from a reevaluation of events in the Garden of Eden. The so-called fall of man represented not a regrettable loss of innocence and fellowship with God but the necessary first step in a process of moral and spiritual development. Destiny, for Adam and Eve, meant through hard work, through action, continually realising more and more of the unlimited potential within them. The concept of sin is notably absent from this process. Certain actions induced feelings of guilt in the individual, but such guilt was real only in the mind of that individual. It did not indicte a serious transgression of an absolute law. Guilt did have the useful function, however, of causing the individual to feel the enormousness of the gulf separating him from perfection. It reminded him, if he needed reminding, that there was a long way to go yet on the road to perfection and that he had better spur his footsteps. What orthodoxy calls original sin, says Lenz, agreeing with Goethe's Pastor, must be explained naturalistically: "Jetzt haben Sie, wann Sie wollen, Principium für die Erbsünde, wann Sie sie so nennen wollen. Ich nenne sie Natur. . . Ich meyne immer, das, was so genannt wird, sey $\mathrm{zu}$ Erreichung unserer Bestimmung durchaus nothwendig."12 Man's first disobedience became necessary because fulfillment of human potential comes by going into action to meet the challenges of existence, not through the easy satisfaction of human needs in a friendly environment. The Mosaic Law, particularly the Ten Commandments that Lenz significantly called the 
Ten Prohibitions, also had the function of preventing an all too easy satisfaction of human desire. Prospects of realising one's personal potential begin to recede the moment the individual exchanges striving for a desire to rest. Lenz's man, no more than Goethe's, may say to the moment: "Verweile doch, du bist so schön." The detailed Israelite laws, especially those governing sexual conduct, were all designed to prevent the attainment of contentment leading to exhaustion, "Erschöpfung," to loss of vigour and eventually to extinction, as the case of the decadent unfaithful portrayed as having drowned in Noah's flood seems to Lenz to illustrate. The righteous who survive are those who, with their ascetic resistence to "concupiscence," rise to new heights of moral living expressed in spontaneously altruistic action. The greatness of the Mosaic Law, felt Lenz, was the very fact that while prohibiting actions harmful to man's development, it prescribed nothing, leaving man to discover on his own what actions were particularly good ones. Such discovery came about through spontaneous action followed by an evaluation of the action.

It was Lenz's study of the Patriarchs that showed him this central lesson of his Heilsgeschichte: "dass sich die Menschen ihere Ideen von Recht und Unrecht hierinnen selber machten--und selber machen mussten, die Vorsicht winkte ihnen nur durch die physischen Erfolge ihrer Handlungen ein Gesetz für derselben zu."13 This empirical learning process was a long one but eventually it culminated in the accession of man to the Age of the Evangelium in which, like Christ, man, of his own accord and with little to fear from any potentially harmful consequences of his actions, is enabled to act out life intensely and altruistically. The second part of the Meynungen, the "Stimmen des Layen," accordingly urges on us the understanding that Christ's teaching is not, any more than the Mosaic Law was, a moral system in which a particular course of conduct is prescribed, but is, in so many words, an authorisation to act as we like: "die Freiheit vor dem Angesicht Gottes zu handeln wie wir wollen." This blunt advocation of amorality is qualified somewhat by Lenz's notion that the real evil in the world consists in apathy and inactivity, whereas action itself, any action, is bound to lead upwards even if it is morally wrong. It was selfevident to Lenz that in the performance of any action, if good is not achieved it was at least attempted, and such attempts are always recognised by God: "Ihr habt einen Gott, der misslungene Versuche nicht mit dem Tode bestraft ${ }_{14}$ sondern mit Leben, ewigem Leben, wenn sie nur fortgesetzt werden." 14

Action at all costs, then, and now not only because it is a sanctified means of moral discovery but also because through Christ it has become a safe means of such discovery. The function of Christ's death was to remove the curse of wrong action, manifested psychologically as feelings of guilt and remorse, and manifested physically as the harmful consequences of foolish action. Action, "Handeln," is guaranteed theologically by Christ's "Verdienst," his merit on behalf of man. Here Lenz takes issue with the orthodox Lutheran position on Christ's merit. In the words of Goethe's Pastor zu *** (whom, incidentally, Lenz takes quite at face value): "Darum verlangt Gott zur Seligkeit keine Thaten, keine Tugenden, sondern den einfältigsten Glauben, und durch den Glauben allein wird uns das Verdienst Christi mitgeteilt."15 Not so, says Lenz, "dieses [Christ's "Verdienst"] legen viele ihrer Faulheit zu einem Polster unter und glauben das 
beste sei, nichts zu tun. Erschröckliche Erklärung die unsere ganze Religion umwirft."16 To Lenz's mind, Christ's sacrificial death is not a reminder of human inadequacy, but is both an encouragement to achieve one's own salvation and a removal of the impediments to human achievement of salvation. Remorse, "Kopfhängen" as the pietist practice of it was popularly called, was one such impediment, condemned throughout Lenz's writings as psychologically harmful as well as theologically wrong. The harmful consequences of foolish actions was another. To Lenz, no action is so wrong that its harmful consequences cannot be made good by subsequent action. There is always a second chance, the failures of the past become pointers to the successes of the future. The proper reaction to failure is not remorse but repentence understood by Lenz in its original sense: metanoia, a change of mentality, a new ability to conceive of higher actions, a new perception of the potential heights of human destiny.

The Bible, understood as "Geschichte der Offenbarungen," has given Lenz a history of incidents in which man discovers for himself what he should be striving for; in every incident action comes first, then moral discovery and moral growth. More importantly this reading of the Bible has given Lenz a theoretical reconciliation between the contemporary desire for spontaneity and freedom of action on the one hand, and the demands of morality on the other. Outside of the Bible he sees two examples of this ethic in Goethe's Götz von Berlichingen, adulated as a Christ-like model of spontaneous, free, altruistic action ("Über Götz"), and Werther, praised by Lenz for the sacramental quality of his actions which lead him to metanoia, to a heightened sense of his existence and his moral potential (Briefe über die Moralität der Leiden des jungen Werthers). Götz and Werther illustrate the dual focus in Lenz on Prometheus and the Prodigal Son. Lenz writes glowingly in Anmerkungen über das Theater of the promethean characters of Shakespearean tragedies and writes to Goethe of his endeavours to rouse the members of the Société to powerful, altruistic action à la Götz: but in his own dramas the figure that predominates is the erring, suffering Prodigal, in whose actions, however, the sacramental quality he noted approvingly in Werther is also evident. The concluding scenes of Der Hofmeister provide the best examples.

In these scenes the problems and obscurities of the plot are all resolved in what has been called an aesthetic solution but which should be seen as a moral and religious solution that reflects Lenz's theological convictions. To be sure, the religious dimension of Lenz's plays, the pietist patterns of sin, suffering, repentance and reconciliation were noted long ago and seen, inevitably, as the involuntary imprint of Lenz's pietistic upbringing. Albrecht Schöne has drawn attention to the fact that New Testament paradigms control the structure of his works and his life, 17 but it has not been so well appreciated that Lenz himself was fully conscious of this fact. In Der Hofmeister these paradigms are just as deliberately invoked as the deliberately and somewhat laboriously explored ideas of the theological essays with which they are intimately connected. A brief outline of the plot will make this clear.

Gustchen has been seduced by the tutor Läuffer, and after fleeing, apparently pregnant, from her father's house, is reduced to penury and despair but is saved at the last minute from committing suicide. Providence, 
on whom she has cast herself, gives her a second chance. Fritz, her cousin and erstwhile truelove, acts idealistically but unwisely during his three year absence at university, but he too is "providentially" saved by a lucky ticket in the lottery and is given a second chance to win Gustchen. Foolish action in both cases becomes a means of moral discovery. Gustchen becomes wise after the event and is able to save Fräulein Rehaar from a fate similar to her own. Fritz realises the folly of making vain vows he could not keep. Gustchen's father, too, recognises the folly of his actions and attitudes, as does Old Pätus, a marginal figure brought in at the end seemingly for no other purpose than to repent of his evil ways. The final line of the play, however trite or however ironic, tells us of one more lesson learned as a result of a questionable action performed: "Wenigstens, mein süsser Junge! werd ich dich nie durch Hofmeister erziehen lassen." Here as well, in the area of education of the young, a second chance is possible, we can do better next time, for it is by making an evaluation of an action performed, even, as in this case, a flippant evaluation, that moral progress is achieved.

It is precisely the notion of moral progress that makes this ending even more a reflection of Lenz's theological convictions. For more has been accomplished than that the main characters have been rescued from the consequences of their folly and been given another chance to redeem themselves. The very discovery of their folly has already raised them several rungs higher on the ladder of moral progress. There is little regret or remorse for past actions in the very last scene of the play because it is realised by the characters concerned that these actions have become sacramental: a means of grace. It is good to have performed them even though they were "misslungene Versuche." Says Fritz: "Dieser Fehltritt macht sie (Gustchen) mir nur noch teurer--macht ihr Herz nur noch englischer. . . Was habe ich von einer solchen Frau anders zu gewarten als einen Himmel?" (my underlining). Acts of folly have all been grist to Pätus's mill as well: "Hier, Papa, ist das Geld, das Sie zu meiner Erziehung in der Fremde angewandt; hier ist's zurück und mein Dank dazu; es hat doppelte Zinsen getragen, das Kapital hat sich vermehrt, und Ihr Sohn ist ein rechtschaffener Kerl worden." All, in the concluding scene of Der Hofmeister, are one step nearer to heaven, not because they did the right thing but precisely because they did the wrong thing but had the sense to learn from their error and for their earnest intentions received a considerable amount of help from Providence.

A very straight reading of a very ambiguous play, to be sure. But the justification for such a reading comes from the strength of Lenz's commitment to the notion of an activism ordained by a benevolent God as a means of moral growth. The Sturm und Drang, with its cult of intensity of experience and spontaneity of action, obviously needed some assurance that such ideals could be safely sought and practised. At a time when Goethe was showing through the sufferings of Werther that such a cult was not safe, Lenz, who saw himself, in Strasbourg at least, as the main theoretician of the movement, developed a theology of action designed to prove that it was not only quite safe but also vitally necessary. As it happened, of course, the theory proved inadequate to deal with the reality in Lenz's personal life of failure and folly, just as it makes somewhat of a mockery at the end of Der Hofmeister of the serious problems uncovered by the plot. 
Lenz's theology took too much notice of the Christian notion of grace, and not enough notice of the equally Christian notion of the tragic reality of evil. Yet it was not without its value and a certain degree of influence. At the very least it was a great advance on the severe dogmatism of Pastor Goeze of Hamburg. More importantly it acted as a corrective to the excessive emphasis in Pietism on remorse for sin. It opposed the urbane scepticism spread, it was felt at the time, by Wieland, and despite Lenz's adulation of Werther it aimed to counter over-sensibility with a practical activism. It seems to have given Lenz himself a vitality that impressed others. Kayser writes to Lenz's friend Röderer in 1776: "O Lenz! Lenz! Lenz! Lenz! könnt' ich dich durch die Winde herreissen lassen, wenn mir so oft Kraft und Muth und Theilnehmung fehlt!"18

University of Lethbridge

NOTES

1 Briefe von und an J.M.R. Lenz, ed. Karl Freye and Wolfgang Stammler, I (Leipzig: Wolff, 1918), p. 67.

2 Of this latter work only the table of contents is now extant. See M.N. Rosanow, Jakob M.R. Lenz: Der Dichter der Sturm- und Drangperiode: Sein Leben und seine Werke (Leipzig: Schulze, 1909), p. 476 , note 143 .

3 Lenz, Gesammelte Schriften, ed Franz Blei, IV (Munich and Leipzig: Müller, 1910), p. 58 .

4 See Lenz's comments in Briefe II, pp. 39, 40.

5 See Ottomar Rudolf, J.M.R. Lenz: Moralist und Aufklärer (Bad Homburg: Gehlen, 1970).

6 A key word in Werner Wien's study, "Lenzens Sturm- und Drangdramen innerhalb seiner religiösen Entwicklung", Diss. Berlin, 1935.

7 Heinz Kindermann, J.M.R. Lenz und die deutsche Romantik (Vienna and Leipzig: Braumüller, 1925), p. 161.

J.M.R. Lenz: Genèse d'une dramaturgie du tragi-comique (Paris: Klincksieck, 1968).

Lenz, Werke und Schriften, ed. Richard Daunicht (Rowohlt, 1970), p. 169.

10 Goethe, Werke, ed. Erich Trunz, Hamburger Ausgabe, X (Hamburg, 1956-), p. 11 . 
11 Lenz, Werke und Schriften, ed. Britta Titel and Helmut Haug, I (Stuttgart: Henry Goverts, 1966), p. 699.

12 Werke und Schriften, ed. Daunicht, p. 171.

13 Ibid., p. 193.

14 "Zweites Supplement," Werke, ed. Titel and Haug, I, p. 508.

15 Goethe's Werke, X (Zurich: Artemis, 1962), p. 657.

16 Werke, ed. Titel and Haug, I, p. 498.

17 Albrecht Schöne, Säkularisation als sprachbildende Kraft: Studien zur Dichtung deutscher Pfarrersöhne, Palaestra 226 (Göttingen, 1958).

18 August Stöber, Johann Gottfried Röderer und seine Freunde (Colmar, $1886)$, p. 50 . 